\title{
PERSEPSI MASYARAKAT PESISIR TERHADAP KEPEMIMPINAN PEREMPUAN NELAYAN DI PULAU PRAMUKA KEPULAUAN SERIBU
}

\author{
Oleh: \\ Ikhsan Fuady ${ }^{1)}$ dan Titien Yusnita ${ }^{2)}$ \\ ${ }^{1)}$ Staf Pengajar Ilmu Komunikasi Universitas Padjajaran \\ ${ }^{2)}$ Staf Pengajar Komunikasi Penyiaran Islam INAIS Sahid Bogor \\ e-mail: $\underline{\text { ikhsan.fuady@unpad.ac.id }}$
}

Naskah diterima: 7 Januari 2016; Direvisi: 6 April 2016; Disetujui: 4 Mei 2016

\begin{abstract}
ABSTRAK
Profesi nelayan adalah profesi yang menuntut kekuatan fisik dan ketangguhan mental. Kehidupan nelayan dalam mengolah sumber daya laut sangat tergantung pada kondisi alam yang tidak stabil. Oleh sebab itu, para isteri nelayan yang lebih dikenal sebagai perempuan nelayan akan melakukan diversifikasi profesi sebagai strategi bertahan hidup. Persepsi masyarakat tentang perempuan nelayan sangat menarik untuk diteliti, mengingat di Pulau Pramuka Kepulauan Seribu, banyak perempuan nelayan dipercaya masyarakat untuk memegang jabatan RT (rukun tetangga) dan untukmendapat julukan sebagai 'penguasa daratan'.Tujuan penelitian ini untuk mengetahui persepsi masyarakat pesisir terhadap kepemimpinan perempuan nelayan dan mengkaji pembagian tugas (division of labor) dalam rumah tangga nelayan pesisir di Pulau Pramuka Kepulauan Seribu.

Penelitian ini menggunakan metode kualitatif dengan pendekatan deskriptif yang menggunakan teknik observasi dan wawancara dengan 25 orang nelayan perempuan dan suaminya yang berprofesi sebagai nelayan serta kepala desa setempat. Hasil penelitian ini menunjukkan bahwa:(1)terjadi perubahan paradigma terhadap kepemimpinan perempuan yaitu perempuan nelayan lebih dipercaya menjabat Ketua RT, (2)pendapat perempuan sangat berpengaruh dalam mengambil keputusan di rumah maupun dalam kehidupan sosial, (3)pembagian tugas (division of labor) dalam rumah tangga nelayan tidak berimbang dimana isteri mengambil alih porsi tanggungjawab yang lebih besar dibandingkan suami mengingat para nelayan pria lebih lama berada di laut dibandingkan di darat.
\end{abstract}

Kata kunci : persepsi, masyarakat pesisir, kepemimpinan, perempuan nelayan

\section{PENDAHULUAN}

\section{LatarBelakang}

Wilayah Kepulauan Seribu secara administrasi pada awalnya berstatus sebagai Kecamatan Pulau Seribu yang merupakan bagian dari wilayah Kota Administrasi Jakarta Utara. Untuk meningkatkan perkembangan di wilayah Kepulauan Seribu dalam segala aspek terutama kelestarian lingkungan, konservasi sumber daya alam (SDA) serta pemberdayaan ekonomi, sosial budaya dan kesejahteraan rakyat, maka kemudian Kecamatan Kepulauan Seribu ditingkatkan statusnya menjadi Kabupaten Administrasi Kepulauan Seribu. Ketentuan ini diatur dalam Undang-Undang Nomor 34 tahun 1999 tanggal 31 Agustus 1999 tentang Pemerintah Provinsi Daerah Khusus Ibukota Negara Republik Indonesia
Jakarta dan Peraturan Pemerintah Nomor 55 tahun 2001 tanggal 3 Juli 2001 tentang Pembentukan Kabupaten Administrasi Kepulauan Seribu, Provinsi Daerah Khusus Ibukota Jakarta. Peningkatan status menjadi Kabupaten Administrasi Kepulauan Seribu diikuti dengan pemekaran Kecamatan dari 1 menjadi 2 Kecamatan dan dari 4 Kelurahan menjadi 6 Kelurahan. Pulau Pramuka ditetapkan sebagai ibukota kabupaten. Berkaitan dengan aspek penataan ruang kemudian disusun Rencana Tata Ruang Wilayah (RT/RW) Kabupaten Administrasi Kepulauan Seribu yang mengacu pada RT/RW Provinsi DKI Jakarta. Berdasarkan Surat Keputusan Gubernur DKI No. 1986/2000 tanggal 27 Juli 2000, secara administrasi Kabupaten Administrasi Kepulauan Seribu memiliki luas wilayah $8,76 \mathrm{Km} 2(875,55 \mathrm{Ha})$ daratan dan dan 
luas lautan 6.997,5 Km2. Wilayah ini terdiri atas dua Kecamatan dan enam Kelurahan, dimana semua Kelurahannya merupakan Kelurahan pesisir pantai dengan jumlah Rukun Tetangga 122 unit.

Hasil pendataan penduduk Kabupaten Administrasi Kepulauan Seribu tahun 2014, jumlah penduduk mencapai 23.876 orang yang terdiri atas 12.058 laki-laki dan 11.818 perempuan. Berdasarkan hasil sensus tersebut, tampak penyebaran penduduk masih terkonsentrasi di Kecamatan Kepulauan Seribu Utara dibandingkan Kecamatan Kepulauan Seribu Selatan, yaitu memiliki jumlah penduduk sebesar 14.635 orang di Kecamatan Kepulauan Seribu Utara dan 9.241 orang di Kecamatan Kepulauan Seribu Selatan. Masyarakat pesisir merupakan masyarakat yang heterogen. Nelayan pesisir merupakan bagian dari masyarakat nelayan kesulitan melepaskan diri dari belenggu kemiskinan karena mereka didera keterbatasan di bidang kualitas sumber daya manusia, akses dan penguasaan teknologi, pasar dan modal. Kebijakan dan implementasi program-program pembangunan untuk masyarakat di kawasan pesisir hingga saat ini masih belum optimal dalam memutus mata rantai kemiskinan dan meningkatkan kesejahteraan mereka. Hal ini disebabkan oleh porsi kebijakan pembangunan bidang sosial, ekonomi dan budaya pada masyarakat nelayan cukup kompleks (Fargomeli 2014).

Strategi masyarakat nelayan dengan melakukan pembagian tugas (division of labor) antara suami (nelayan) dengan isteri (perempuan nelayan) dalam memenuhi kebutuhan keluarga cukup efektif dijalankan walaupun masih terdapat ketimpangan beban kerja yang lebih besar pada perempuan nelayan. Melalui diversifikasi profesi, perempuan nelayan sangat memegang peranan 'di darat' baik dalam menentukan urusan keluarga hingga mengurus kepentingan masyarakat di sekitarnya dengan berkiprah sebagai pemimpin masyarakat di lingkungan Rukun Tetangga (RT). Penelitian ini bertujuan untuk mengetahui kiprah perempuan nelayan dalam kepemimpinannya dalam masyarakat nelayan pesisir khususnya di Pulau Pramuka Kepulauan Seribu. Sekaligus juga untuk mengetahui pembagian tugas rumah tangga (division of labor) antara isteri dan suami yang berprofesi nelayan dalam memenuhi kebutuhan hidup rumah tangga.

\section{RumusanMasalah}

Dari uraian yang telah dikemukakan maka dapat dibuat rumusan masalah berikut :

a. Bagaimana persepsi masyarakat pesisir terhadap kepemimpinan perempuan nelayan di Pulau Pramuka Kepulauan Seribu?

b. Bagaimana pembagian tugas (division of labor) dalam rumah tangga nelayan pesisir di Pulau Pramuka Kepulauan Seribu?

\section{TujuanPenelitian}

Tujuan penelitian adalah :

a. Mengetahuipersepsimasyarakatpesisi $r$ terhadap kepemimpinan perempuan nelayan di Pulau Pramuka Kepulauan Seribu

b. Mengkaji pembagian tugas (division of labor) dalam rumah tangga nelayan pesisir di Pulau Pramuka Kepulauan Seribu?

\section{KAJIAN PUSTAKA}

\section{PengertianPersepsi}

Persepsi adalah proses dengan mana kita menjadi sadar akan banyaknya stimulus yang mempengaruhi indra kita. Persepsi mempengaruhi rangsangan (stimulus) atau pesan apa yang kita serap dan makna apa yang kita berikan kepada mereka ketika mereka 
mencapai kesadaran (DeVito 1997). Menurut Rakhmat (1998) menyatakan persepsi adalah pengalaman tentang obyek, peristiwa, atau hubunganhubungan yang diperoleh dengan menyimpulkan informasi dan menafsirkan pesan. Proses persepsi bukan hanya proses psikologi semata, tetapi diawali dengan proses fisiologis yang dikenal sebagai sensasi. Schiffman dan Kanuk dalam Suryani (2008) mendefinisikan persepsi sebagai proses dimana dalam proses tersebut individu memilih, mengorganisasikan dan menginterpretasikan stimuli menjadi sesuatu yang bermakna.

Dari uraian yang dikemukakan, dapat dipahami proses persepsi sangat penting dalam kajian ini mengingat bentuk dan fungsinya meliputi tiga hal berikut : (1)proses persepsi, dimana dapat dipahami bahwa segala sesuatu yang terjadi di luar pikiran manusia belum tentu sama dengan yang dipikirkannya. DeVito (1997) menyatakan proses-proses dalam persepsi yaitu apa yang dilihat dan apa yang dilihat serta apa yang disimpulkan dan tidak kita simpulkan mempengaruhi kita dalam menata banyak data yang memasuki alat indra kita; (2)proses yang mempengaruhi persepsi, menjelaskan bahwa antara kejadian stimulasi (sampainya sebuah pesan, keberadaan seseorang, senyum atau lirikan mata) dengan evaluasi atau penafsiran terhadap stimulasi tersebut sehigga membuat persepsi dipengaruhi oleh berbagai proses psikologis penting; (3)atribusi (attribution), yaitu proses dengan mana mengartikan perilaku kita sendiri dan orang lain. Atribusi mengacu pada proses dimana mencoba memahami perilaku diri sendiri dan perilaku orang lain serta motivasi perilakunya. Dalam menggunakan atribusi diri dalam usaha menilai perilaku diri sendiri dengan mengikuti prinsip-prinsip umum yang sama seperti bila menilai perilaku orang lain. Terdapat dua perbedaan penting, dimana kita menganggap perilaku disebabkan oleh faktor luar dan bukan faktor dalam serta kita biasanya bersikap ingin menang sendiri (self-service bias). Proses persepsi dalam diri mempunyai hambatan apabila, seseorang sudah memiliki citra tentang orang lain yang disebut sebagai stereotipe, yaitu citra yang melekat atas sekelompok orang (kelompok bangsa, kelompok agama, kelompok ras dan seterusnya) yang sulit untuk diubah. Stereotipe mendistorsi kemampuan untuk mempersepsikan orang lain secara akurat, disamping menghalangi melihat seseorang sebagai seseorang dan bukan sekadar sebagai anggota suatu kelompok saja.

\section{Karakteristik Masyarakat Nelayan}

Imron (2003) menyatakan nelayan adalah suatu kelompok masyarakat yang kehidupannya tergantung langsung pada hasil laut, baik dengan cara melakukan penangkapan ataupun budi daya. Nelayan umumnya tinggal di pinggir pantai, sebuah lingkungan pemukiman yang dekat dengan lokasi kegiatannya. Kusnadi (2004) menyatakan secara geografis, masyarakat nelayan adalah masyarakat yang hidup, tumbuh dan berkembang di kawasan pesisir, yakni suatu kawasan transisi antara wilayah darat dan laut. Sastrawidjaya (2002) menyatakan nelayan adalah orang yang hidup dari mata pencaharian hasil laut. Di Indonesia para nelayan biasanya bermukin di daerah pinggir pantai atau pesisir laut. Komunitas nelayan adalah kelompok orang yang bermata pencaharian hasil laut dan tinggal didesa-desa atau pesisir.

Karakteristik masyarakat nelayan dapat dibagi dua berdasarkan teknologi peralatan tangkap yang digunakan, yaitu: (1)nelayan moderen dan (2)nelayan tradisional. Nelayan moderen menggunakan teknologi penangkapan lebih canggih dibandingkan dengan nelayan tradisional. Ukuran modernitas bukan 
semata-mata karena pengunaan motor untuk mengerakkan perahu, melainkan besar kecilnya motor yang digunakan dan tingkat eksploitasi dari alat tangkap yang digunakan. Perbedaan modernitas teknologi alat tangkap juga akan berpengaruh pada kemampuan jelajah operasionalnya (Imron 2003). Dari penggunaan alat tangkap tersebut, masyarakat nelayan menghadapi masalah terkait bidang politik, sosial dan ekonomi yang kompleks. Masalahmasalah tersebut bermuara pada kemiskinan, kesenjangan sosial dan tekanan-tekanan ekonomi yang datang setiap saat.

\section{Penggolongan Masyarakat Nelayan}

Fargomeli (2014) menyatakan pada dasarnya kelompok masyarakat nelayan memiliki beberapa perbedaan dalam karakteristik sosial. Perbedaan tersebut dapat dilihat pada kelompok umur, pendidikan, status sosial dan kepercayaan. Dalam satu kelompok nelayan sering ditemukan perbedaan kohesi internal, dengan pengertian hubungan sesama nelayan maupun hubungan bermasyarakat (Townsley 1998). Widodo (2006) membagi kelompok nelayan dalam empat kelompok yaitu: (1)Nelayan subsisten (subsistence fishers), yaitu nelayan yang menangkap ikan hanya untuk memenuhi kebutuhan sendiri; (2)Nelayan asli (native/indigenous/aboriginal fishers), yaitu nelayan yang sedikit banyak memiliki karakter sama dengan kelompok pertama, namun memiliki hak melakukan aktivitas secara komersial walaupun dalam skala sangat kecil; (3)Nelayan rekreasi (recreational/sport fishers), yaitu orang-orang yang secara prinsip melakukan kegiatan penangkapan hanya sekedar untuk kesenangan atau berolahraga, dan (4)Nelayan komersial (commercial fishers), yaitu menangkap ikan untuk tujuan komersial atau dipasarkan baik untuk pasar domestik maupun pasar ekspor. Kelompok nelayan ini dibagi dua, yaitu nelayan skala kecil dan skala besar.

Selain pembagian kelompok nelayan diatas juga terdapat terminologi yang sering digunakan untuk menggambarkan kelompok nelayan, seperti: nelayan penuh untuk yang menggantungkan keseluruhan hidupnya dari menangkap ikan; nelayan sambilan untuk yang hanya sebagian dari hidupnya tergantung dari menangkap ikan (lainnya dari aktivitas seperti pertanian, buruh dan tukang); juragan (patron atau tauke) untuk yang memiliki sumber daya ekonomi untuk usaha perikanan seperti kapal dan alat tangkap; dan anak buah kapal (ABK) untuk yang mengalokasikan waktunya dan memperoleh pendapatan dari hasil pengoperasian alat tangkap ikan, seperti kapal milik juragan.

\section{Gender dan Stereotipe}

Narwoko dan Suyanto (2004) menyatakan bahwa gender adalah pelabelan terhadap pihak tertentu yang selalu berakibat merugikan pihak lain dan menimbulkan ketidakadilan. Dalam budaya patriarki, konsep gender membedakan perempuan dan laki-laki berdasarkan konstruksi sosial membuat perempuan terkonsep sebagai perempuan yang lemah, tidak berdaya dan tidak tegas membuat laki-laki menjadi pihak dominan. Laki-laki dikondisikan selalu benar, logis, tegas, tidak boleh lemah atau cengeng dan harus siap melindungi perempuan, hingga yang terjadi adalah penempatan kekuasaan menjadi milik laki-laki.

Konsep gender menimbulkan pembagian peran antara perempuan dan laki-laki di dalam kehidupan rumah tangga dan masyarakat. Perempuan memiliki peran dan tanggungjawab terhadap pemeliharaan keutuhan keluarga atau rumah tangga, sedangkan laki-laki memiliki peran dan tanggungjawab dalam hal pemenuhan 
ekonomi keluarga. Peran yang berbeda antara perempuan dan laki-laki dalam keluarga dan masyarakat merupakan akibat dari pembagian pekerjaan secara seksual. Dalam hal ini, perempuan hamil, melahirkan dan menyusui lebih dihubungkan dengan pekerjaanpekerjaan reproduktif. Pekerjaanpekerjaan yang termasuk jenis pekerjaan ini antara lain pekerjaan tumah tangga dan merawat anak. Sebaliknya, laki-laki lebih dihubungkan dengan pekerjaanpekerjaan yang berada di luar rumah atau produksi (sektor publik). Dari pembagian peran tersebut timbul anggapan bahwa kekuatan fisik perempuan tidak lebih dari laki-laki, sehingga perempuan adalah makhluk lemah. Anggapan itu melahirkan nilainilai yang menempatkan perempuan sebagai makhluk "kelas dua" lengkap dengan pencitraan-pencitraan yang tidak semuanya menguntungkan perempuan, bahkan sebaliknya. Nilai-nilai itulah yang dianut, disosialisasikan dan dipraktekkan secara keseharian, sekaligus mempengaruhi ketidakseimbangan relasi gender yang merugikan perempuan. Griffin (2000) menyatakan tentang Muted Theory (kelompok yang terbungkam), dimana kaum perempuan sulit untuk menyampaikan keberatannya dalam sebuah percakapan karena kontrol komunikasi yang dikuasai kaum patriarki cenderung tidak menguntungkan perempuan, sehingga dalam banyak diskusi di ruang publik, kaum perempuan lebih memilih bungkam (diam).

Teori Nature menjelaskan bahwa peran perempuan dan laki-laki dibedakan atas dasar faktor biologis, sedangkan Teori Nurture merupakan salah satu teori gender yang meyakini bahwa adanya perbedaan antar perempuan dan laki-laki pada hakekatnya adalah bentukan masyarakat melalui konstruksi sosial budaya, sehingga menghasilkan peran dan tugas yang berbeda. Perbedaan itu menyebabkan perempuan selalu tertinggal dan terabaikan peran dan kontribusinya dalam hidup berkeluarga, bermasyarakat, berbangsa dan bernegara. Konstruksi sosial menempatkan perempuan dan laki-laki dalam perbedaan kelas. Laki-laki diidentikkan dengan kelas borjuis, dan perempuan sebagai proletar (Puspitawati 2009). Dinyatakan pula bahwa faktor-faktor sosial dan budaya dapat menciptakan atribut gender serta membentuk stereotip dari jenis kelamin tertentu. Hal tersebut terjadi selama masa pengasuhan orang tua atau masyarakat terulang secaraturun temurun(Lippa 2005).Budaya patriarki dapat didefinisikan sebagai suatu sistem yang bercirikan laki-laki sebagai contoh dalam keluarga, misalnya: kedudukan isteri tergantung suami, kedudukan anak perempuan tergantung pada ayah atau saudara laki-laki, dan seterusnya.

\section{Paradigma Fungsionalisme dan Feminisme \\ Aliran fungsionalisme struktural atau sering disebut aliran} fungsionalisme, adalah aliran arus utama (mainstream) dalam ilmu sosial yang dikembangkan oleh Robert Merton dan Talcot Parsons. Teori ini menyatakan bahwa masyarakat adalah suatu sistem yang terdiri atas bagian dan saling berkaitan (agama, pendidikan, struktur politik, hingga keluarga) dan masingmasing berusaha mencapai keseimbangan (equilibrium) dan keharmonisan, sehingga dapat menjelaskan kaum perempuan (Narwoko \& Suyanto 2004). Teori ini menganalisis tentang struktur sosial masyarakat yang terdiri dari berbagai unsur yang saling terkait, meskipun memiliki fungsi berbeda. Perbedaan fungsi tersebut justru diperlukan untuk saling melengkapi sehingga suatu sistem yang seimbang dapat terwujud. Dalam teori struktural fungsional, konsep 
gender dibentuk menurut pembagian peran dan fungsi masing-masing lakilaki dan perempuan.

\section{METODE PENELITIAN}

Metode penelitian menggunakan pendekatan kualitatif. Lokasi penelitian di Pulau Pramuka Kepulauan Seribu. Penelitian ini untuk mengetahui bagaimana kehidupan sosial ekonomi perempuan nelayan sebagai ibu rumah tangga sekaligus sebagai pencari nafkah keluarga, serta bagaimana mutu hidup perempuan nelayan di Pulau Pramuka. Mengingat belum pernah ada penelitian mengenai kehidupan sosial ekonomi perempuan dalam masyarakat nelayan di Pulau Pramuka Kepulauan Seribu merupakan alasan peneliti memilih topik penelitian ini.

Sumber data dalam penelitian ini dibedakan menjadi dua, yaitu,(1)sumber data primer berupa informasi dari pihakpihak yang terkait dengan obyek penelitian yaitu perempuan nelayan sebagai ibu rumah tangga dan perempuan nelayan yang melakukan diversifikasi profesi (misal : pedagang, asisten rumah tangga, juru masak, pembuat cinderamata dan lain-lain), suami yang berprofesi sebagai nelayan dan nelayan yang melakukan diversifikasi profesi, serta kepala desa, (2)sumber data sekunder berupa arsip dan dokumen yang berkaitan dengan obyek penelitian.

Pengumpulan data menggunakan : (1)wawancara yang dilakukan kepada 25 orang ditujukan kepada perempuan nelayan sebagai ibu rumah tangga dan yang melakukan diversifikasi profesi, suami yang berprofesi sebagai nelayan dan yang juga melakukan diversifikasi profesi, serta kepala desa, (2)dokumentasi bertujuan untuk memperkuat data yang diperoleh dari wawancara yang berkaitan dengan permasalahan penelitian, (3)metode observasi di lapangan.

\section{PEMBAHASAN}

\section{Karakteristik Rumah Tangga Nelayan \\ a. Kemiskinan dalam rumah tangga nelayan}

Kemiskinan dalam rumah tangga nelayan dapat dengan mudah terlihat kondisi tempat tinggal mereka. Keterbatasan akses modal, teknologi dan pasar sehingga memengaruhi dinamika usaha, kelemahan fungsi kelembagaan sosial ekonomi yang ada, kualitas sumber daya manusia yang rendah sebagai akibat keterbatasan akses pendidikan, kesehatan dan pelayanan publik, degradasi sumber daya lingkungan baik di kawasan pesisir, laut, maupun pulau-pulau kecil, dan lemahnya kebijakan yang berorientasi pada kemaritiman sebagai pilar utama pembangunan nasional (Kusnadi 2004). Masalah aktual lain yang perlu diperhatikan adalah potensi berkembangnya jumlah penduduk miskin di kawasan pesisir cukup terbuka.

Kondisi diatas diperparah dengan meningkatnya kerusakan di lingkungan pesisir. Degradasi lingkungan ini terjadi karena pembuangan limbah dari wilayah darat ke lautan. Selain itu, kebijakan pemerintah daerah tentang perubahan tata guna lahan di kawasan pesisir untuk kepentingan pembangunan fisik menambah panjang masalah yang harus dihadapi oleh nelayan. Kondisi demikian semakin menyulitkan nelayan memperoleh hasil tangkapan, khususnya di daerah-daerah perairan yang kondisi tangkap lebih. Kesulitan teknis lainnya, yaitu meningkatnya biaya-biaya operasi penangkapan karena harga bahan bakar minyak (bensin dan solar) yang tidak stabil sehingga nelayan mengurangi kuantitas operasi penangkapan.

\section{b. Gender dan Beban Kerja}


Strategi diversifikasi profesi merupakan pilihan perempuan nelayan untuk tetap bertahap hidup, apabila suaminya tidak pergi melaut atau hasil tangkapan ikan yang tidak memadai. Persepsi masyarakat selama ini tentang kaum perempuan yang memiliki kewajiban seperti: memelihara, rajin, tidak pantas menjadi kepala rumah tangga, apalagi menjadi pemimpin di masyarakat, membuat beban kerja nelayan perempuan miskin mempunyai beban ganda. Di kalangan keluarga nelayan miskin, beban berat harus dikerjakan sendiri disamping tugas-tugas domestik lainnya. Hal ini berbeda dengan perempuan nelayan yang berkecukupan dimana beban kerjanya dilimpahkan sebagian pada asisten rumah tangga (domestic worker).

Persepsi masyarakat bahwa pekerjaan domestic worker adalah 'pekerjaan perempuan'dan bukan 'pekerjaan laki-laki' berakibat pada pekerjaan rumah tangga dianggap tidak produktif. Mosser (1999) menyatakan bahwa perempuan tidak hanya berperan ganda akan tetapi perempuan memiliki triple role (triple burden) yaitu : peran reproduksi (peran yang berhubungan dengan peran tradisional di sektor domestik), peran produktif (peran ekonomis di sektor publik) dan peran sosial (peran di komunitas). Masithoet.al (2013) mengungkapkan World Health Organization mendefinisikan quality of life atau kualitas hidup sebagai persepsi individu terhadap kehidupannya di masyarakat dalam konteks budaya dan sistem nilai yang ada yang terkait dengan tujuan, harapan, standar, dan juga perhatian terhadap kehidupan. Kualitas hidup dalam hal ini merupakan suatu konsep yang sangat luas yang dipengaruhi oleh kondisi fisik individu, psikologi, tingkat kemandirian dan hubungan sosial individu dengan lingkungannya.Hasil survei di Pulau Pramuka Kepulauan Seribu menunjukkan bahwa dari delapan RT yang saat ini menjabat terdapat tujuh orang Ketua RT yang dijabat oleh perempuan secara terinci pada Tabel 1 .

Tabel 1. Daftar nama Ketua RT di Pulau Pramuka Kepulauan Seribu

\begin{tabular}{|c|c|c|c|}
\hline Nama & $\begin{array}{c}\text { Ketu } \\
\text { a } \\
\text { RT/R } \\
\text { W }\end{array}$ & Perkerjaan & $\begin{array}{c}\text { Pekerjaans } \\
\text { uami }\end{array}$ \\
\hline Hilda & $\begin{array}{c}01 / 0 \\
4\end{array}$ & $\begin{array}{l}\text { Iburumahtan } \\
\text { gga }\end{array}$ & PNS \\
\hline $\begin{array}{l}\text { Murtas } \\
\text { iah }\end{array}$ & $\begin{array}{c}02 / 0 \\
4\end{array}$ & $\begin{array}{l}\text { Pedagang } \\
\text { ikan }\end{array}$ & Buruh \\
\hline $\begin{array}{l}\text { Suryan } \\
\text { ti }\end{array}$ & $\begin{array}{c}03 / 0 \\
4\end{array}$ & $\begin{array}{l}\text { Iburumahtan } \\
\text { gga }\end{array}$ & PNS \\
\hline $\begin{array}{l}\text { Kutsiy } \\
\text { ah }\end{array}$ & $\begin{array}{c}04 / 0 \\
4\end{array}$ & $\begin{array}{l}\text { Iburumahtan } \\
\text { gga }\end{array}$ & PNS \\
\hline Lusia & $\begin{array}{c}01 / 0 \\
5\end{array}$ & $\begin{array}{l}\text { Penguruspos } \\
\text { yandu }\end{array}$ & $\begin{array}{l}\text { Pegawaiho } \\
\text { norer }\end{array}$ \\
\hline Eliana & $\begin{array}{c}03 / 0 \\
5\end{array}$ & $\begin{array}{l}\text { Iburumahtan } \\
\text { gga }\end{array}$ & Lurah \\
\hline $\begin{array}{l}\text { Badria } \\
\mathrm{h}\end{array}$ & $\begin{array}{c}04 / 0 \\
5\end{array}$ & Guru honorer & Buruh \\
\hline
\end{tabular}

Berdasarkan Muted Theory (kaum yang terbungkam) oleh Ardener dan Shirley yang menyatakan bahwa bahasa yang digunakan perempuan dibentuk dan dikembangkan secara luas oleh persepsi laki-laki tentang realitas dengan asumsi dasar berikut: (1) perempuan mempersepsikan dunia secara berbeda dari laki-laki karena perempuan dan lakilaki memiliki pengalaman dan aktivitas berbeda; (2) laki-laki adalah kelompok dominan dalam masyarakat yang membuat perspektif perempuan tidak lebih kompeten; (3) agar bisa berpartisipasi dalam lingkungan sosial, perempuan harus mengubah model ekspresi komunikasinya agar bisa diterima oleh sistem ekspresi laki-laki (Kramarae 1981). Ibu Murtasiah (Ketua RT 02/04) ketika mempunyai permasalahan dengan suaminya lebih memilih untuk diam daripada terjadi konflik. Ketika berpendapat pendapatnya juga didengarkan oleh suaminya, walau terkadang pendapatnya disetujui terkadang tidak. Pengambilan 
keputusan dikontrol oleh suaminya, seperti ketika ada undangan rapat di luar pulau, Ibu Murtasiah dilarang suaminya untuk datang karena cuaca buruk. Di dalam masyarakat, ada perempuan yang berani berbicara dan ada juga yang tidak banyak bicara. Bahkan ada perempuan yang minta pendapatnya diwakilkan perempuan lain dalam komunikasi verbal pada rapat warga. Bila terjadi konflik antara pasangan nelayan di rumah tangga tidak jarang keduanya tetap pada pendiriannya sehingga tidak dicapai kesepakatan, misalnya isteri ingin bekerja di luar rumah, tetapi dilarang oleh suaminya dengan alasan agar isteri tetap menjadi penanggungjawab utama rumah tangga (domestic worker). Dengan alasan perekonomian keluarga, isteri tetap bekerja di luar rumah, walaupun meninggalkan tugas utamanya yang sebetulnya dapat dikerjakan bersamasama suaminya demi memperjuangkan kebutuhan keluarga. Partisipasi perempuan untuk membantu perekonomian keluarga dengan beralih profesi dari nelayan menjadi pedagang, penjahit, kuli cuci pakaian, merawat tempat penginapan bahkan menjadi Ketua RT.

Sebagai kajian teori yang kedua adalah Standpoint Theory (sudut pandang) yang dijelaskan oleh Krolokke dan Sorensen (2006) sebagai teori pertama dan paling awal dalam menjelaskan hubungan antara kekuasaan dan pengetahuan. Menurut teori ini perempuan dinyatakan memiliki visi ganda. Yang menjadi penekanan dalam hal ini adalah penilaian wanita itu sendiri terhadap perbedaan kelas, ras/etnis dan jenis kelamin. Secara umum tidak ada perbedaan pandangan dan perlakuan antara pria dan wanita dalam segala bidang. Seperti contohnya adalah pendatang, baik pria maupun wanita, selama dapat beradaptasi, para pendatang memiliki hak dan kewajiban yang sama dengan penduduk asli Pulau Pramuka.

Pada kelas sosial biasa dijumpai terjadi perbedaan perlakuan antara 'orang kaya' dan 'orang miskin' (tidak mampu). Bagi nelayan, persepsi orang kaya dilihat dari kepemilikan materi seperti mempunyai penginapan ternama atau kapal penyeberangan komersil di Pulau Pramuka. Perbedaan status ini menimbulkan kecemburuan sosial, sehingga memandang rendah orang miskin yang selalu merasa diperlakukan tidak adil oleh orang lain, misalnya sudut pandang 'orang miskin' tentang perlakuan guru di sekolah kepada anak yang tidak mampu dan tidak pintar, sudut pandang 'orang miskin' terhadap tetangganya, karena merasa tidak diajak bersosialisasi di lingkungan tempatnya tinggal. Sudut pandang (standpoint theory) dalam hal ini menjelaskan bagaimana sudut pandang 'orang miskin' tentang kekuasaan yang diidentikkan pada 'orang kaya' yang diukur dari kepemilikan materinya. Dalam kehidupan masyarakat nelayan, orang kaya dikenal dengan istilah patron atau bakul atau taukeatau juragan yaitu nelayan pemilik modal besar atau pemilik kapal tangkap ikan dan orang miskin biasanya diwakili oleh nelayan buruh atau nelayan asli (hasil tangkapan ikan hanya untuk dikonsumsi keluarganya sehari-hari).

\section{c. Karakteristik Masyarakat Nelayan \\ Townsley dalam Widodo (2006)} menyatakan pada dasarnya kelompok masyarakat nelayan memiliki beberapa perbedaan dalam karakteristik sosial. Perbedaan tersebut dapat dilihat pada kelompok umur, pendidikan, status sosial dan kepercayaan. Dalam satu kelompok nelayan sering juga ditemukan perbedaan kohesi internal, dengan pengertian hubungan sesama nelayan maupun hubungan bermasyarakat. Charles dalam Widodo 
(2006) membagi kelompok nelayan dalam empat kelompok, yaitu: (1)Nelayan subsisten (subsistence fishers), yaitu nelayan yang menangkap ikan hanya untuk memenuhi kebutuhan sendiri; (2)Nelayan asli (native/indigenous/aboriginal fishers), yaitu nelayan yang sedikit banyak memiliki karakter sama dengan kelompok pertama, namun memiliki juga hak untuk melakukan aktivitas secara komersial walaupun dalam skala sangat kecil; (3)Nelayan rekreasi (recreational/sport fishers), yaitu orangorang yang secara prinsip melakukan kegiatan penangkapan hanya sekedar untuk kesenangan atau berolahraga, dan (4)Nelayan komersial (commercial fishers), yaitu yang menangkap ikan untuk tujuan komersial atau dipasarkan baik untuk pasar domestik maupun pasar ekspor. Kelompok nelayan ini dibagi dua, yaitu nelayan skala kecil dan skala besar.

Nelayan subsisten dan nelayan asli lebih dikenal dengan nelayan buruh dimana mereka tidak memiliki modal usaha berupa uang, peralatan memancing atau mengolah ikan masih menggunakan teknologi sederhana serta tidak memiliki kapal tangkap ikan sendiri sehingga harus meminjam dari nelayan yang memiliki sumber daya dan akses modal yang besar yang dikenal dengan istilah 'patron/tauke/juragan/boss'. Sesuai dengan pembagian dalam penelitian Widodo (2006) maka nelayan yang bermodal besar tersebut dikenal dengan istilah nelayan komersil.

Hubungan kerjasama yang erat antara patron (tauke/juragan/boss) dengan kliennya (nelayan buruh) terjalin dalam waktu panjang dan meliputi hampir seluruh aspek kehidupan keduanya. Patron berperan selaku 'penguasa' melakukan komunikasi interpersonal dengan nelayan buruh selaku 'klien' untuk membantu menyelesaikan masalah yang dialami nelayan buruh dalam kesehariannya. Patron selaku penguasa selalu siap membantu nelayan buruh untuk meminjamkan modal usaha baik berupa uang, barang (kapal, alat pancing dan lain-lain) dan modal usaha (barang dagangan berupa suvenir, makanan olahan dari laut dan lain-lain). Sedangkan nelayan buruh tanpa sadar 'telah terhutang budi' pada patron yang membantunya untuk membayar biaya sekolah anak, biaya berobat, biaya melahirkan, membeli kebutuhan sembako, biaya menikah/hajatan/khitanan dan seterusnya. Patron yang memiliki modal keuangan yang cukup besar ini bersedia memberi pinjaman pada nelayan buruh tanpa jaminan lalu sistem pembayaran disepakatidengan cara dicicil setiap bulan, walaupun dalam waktu yang cukup lama dengan jaminan seluruh hasil tangkapan ikan nelayan buruh dijual kepada patron tersebut dengan harga yang telah ditentukan oleh 'sang patron'. Sekilas hubungan kerjasama keduanya saling menguntungkan, tetapi pada kenyataannya nelayan buruh tetap hidup dalam garis kemiskinan. Hutang yang dicicil dalam waktu yang lama belum kunjung lunas tetapi disusul kebutuhan keluarga yang terus meningkat sehingga hutang demi hutang pun ditumpuk hingga nelayan buruh tidak berdaya apalagi menjadi mandiri. Hal inilah yang disebut dengan kemiskinan terstruktur.

Relasi patron-klien terjadi juga di Pulau Pramuka Kepulauan Seribu. Nelayan perempuan berusaha keras melakukan diversifikasi profesi untuk memenuhi kebutuhan hidup keluarga. Peran para ketua RT yang notabene perempuan dalam menggiatkan dan meningkatkan kemampuan perempuan nelayan patut diapresiasi. Dengan membentuk kelompok-kelompok wanita nelayan, mereka mengadakan kegiatan yang diharapkan mampu meningkatkan keahlian guna mempermudah akses 
permodalan dan pendapatan keluarga. Kemampuan mengolah hasil perikanan atau sumber daya kelautan terus digalakkan melalui kelompok-kelompok perempuan nelayan dengan memanfaatkan pelatihan-pelatihan yang didukung oleh Pemda DKI Jakarta, pihak swasta (produsen) dan lembaga swadaya masyarakat. Hanya saja pelatihan ini masih bersifat parsial dan belum mampu melibatkan sebagian besar perempuan nelayan di Pulau Pramuka Kepulauan Seribu.

\section{d. Konsep Pemberdayaan Perempuan Nelayan}

Narwoko dan Suyanto (2011) menyatakan paradigma pembangunan hanya mengutamakan faktor ekonomi, khususnya pertumbuhan ekonomi tanpa memperhatikan aspek lain, seperti aspek-aspek kemanusiaan mengakibatkan hasil pembangunan yang tidak merata bahkan memperlebar jurang kemiskinan, khususnya pada kaum perempuan. Pembangunan yang tidak membedakan gender antara laki-laki dan perempuan justru menimbulkan kesenjangan gender (gender gap). Kesenjangan gender di berbagai bidang pembangunan dapat dilihat dari : (1)masih rendahnya peluang yang dimiliki perempuan untuk bekerja; (2)rendahnya akses perempuan terhadap sumber daya ekonomi, seperti: teknologi, informasi, pasar, kredit dan modal kerja; (3)pembagian kerja yang tidak adil antara laki-laki dan perempuan, dimana perempuan telah terlibat dalam pekerjaan produksi tetapi pekerjaan domestik di rumah tangga masih menjadi beban tanggungjawab perempuan; (4)posisi perempuan di wilayah sosial politik masih rendah dibandingkan dengan laki-laki; (5)meskipun penghasilan perempuan pekerja memberikan kontribusi cukup nyata terhadap penghasilan dan kesejahteraan keluarga, namun perempuan masih dianggap sebagai pencari nafkah tambahan dan dianggap tenaga cadangan (sekunder).

Khusus dunia ketiga terdapat lima pendekatan kebijakan untuk memberdayakan perempuan termasuk perempuan nelayan, yaitu :

\section{Pendekatan Kesejahteraan (social welfare)}

Terdapat tiga asumsi pada pendekatan kesejahteraan. Pertama, perempuan dianggap lebih sebagai penerima pasif daripada sebagai subjek pembangunan. Kedua, peran pengasuhan (motherhood) merupakan peran yang paling penting bagi perempuan dalam masyarakat. Ketiga, mengasuh anak adalah peran perempuan yang paling efektif dalam semua aspek pembangunan ekonomi. Pendekatan ini berorientasi pada keluarga, dengan pusat perhatian pada kelompok perempuan dengan peran produktif (mengasumsikan laki-laki memiliki peran produktif pula), hubungan antara ibu-anak menjadi pusat perhatian. Implementasi pendekatan ini melalui pemberian bantuan secara cuma-cuma secara top down, meningkatkan keterampilan kaum perempuan untuk meningkatkan kesejahteraan keluarga. Perempuan nelayan pun tidak luput dari bantuan cuma-cuma secara top down hanya saja pendekatan ini menimbulkan ketergantungan perempuan bahkan tidak membantu perempuan untuk lebih mandiri. Pendekatan kesejahteraan seringkali digunakan sebagai penyelesaian masalah yang paling praktis dan tidak beresiko secara politis, misalnya pemberian dana Bantuan Langsung Tunai (BLT) dan Pendidikan Keluarga Harapan $(\mathrm{PKH})$ yang sangat strategik, sehingga menimbulkan ketergantungan kaum perempuan dan berdampak pada sulitnya mencapai kemandirian. 


\section{Pendekatan Keadilan}

Pendekatan ini menyadari bahwa perempuan adalah peserta aktif dalam proses pembangunan. Melalui peran reproduktif dan produktif, perempuan memberi sumbangan penting, meskipun sumbangan tersebut sering tidak diakui bagi pertumbuhan ekonomi. Berdasarkan pengalaman, strategi-strategi ekonomi seringkali berdampak negatif pada perempuan.Oleh karena itu perempuan harus dilibatkan dalam pembangunan dengan meningkatkan akses dan kesempatan kerja, sehingga pendekatan ini menyadari kebutuhan praktis gender dalam memperoleh pekerjaan. Selain itu, pendekatan kesejahteraan lebih mementingkan kemandirian ekonomi sebagai wujud keadilan. Tabel 1 menunjukkan profesi Ketua RT perempuan di Pulau Pramuka Kepulauan Seribu sangat beragam (ibu rumah tangga, pedagang, guru dan pekerja sosial), tetapi semuanya dapat berkontribusi dalam masyarakat nelayan melalui program kerja tanpa membedakan gender.

\section{Pendekatan Anti Kemiskinan}

Asumsi pendekatan anti kemiskinan bahwa akar kemiskinan dari perempuan dan ketimpangannya dengan laki-laki disebabkan lemahnya kepemilikan tanah dan kepemilikan modal secara pribadi dan diskriminasi seksual pada pasar kerja. Oleh karena itu, diperlukan adanya kebebasan untuk memperoleh kesempatan kerja dan peningkatan penghasilan di kalangan perempuan kelas bawah dengan membuka akses terhadap sumber-sumber ekonomi (akses terhadap sumber daya produktif). Oleh sebab itu, sasaran program yang dituju ialah pada kebutuhan strategis, terutamapada program $\mathrm{KB}$ untuk mengurangi kelahiran, program pendidikan dan ketenagakerjaan. Saat ini Dinas Pendidikan di Pulau Pramuka Kepulauan Seribu sedang giat mempromosikan pada masyarakat program 'Wajib Belajar 12 tahun demi meningkatkan mutu sumber daya manusia (SDM), khususnya bagi nelayan perempuan.

\section{Pendekatan Efisiensi}

$\begin{array}{lcr}\text { Pendekatan } & \text { efisiensi } & \text { lebih } \\ \text { menekankan } & \text { pada } & \text { program } \\ \text { pembangunan. } & \text { Mosse } & (1996) \\ \text { mengemukakan } & \text { asumsi } & \text { bahwa } \\ \text { partisipasi ekonomi } & \text { dapat }\end{array}$ meningkatkan status perempuan, dan berkaitan dengan keadilan telah dikritik secara luas, seperti faktor penghambat partisipasi perempuan misalnya tingkat pendidikan rendah diperburuk dengan akses teknologi yang kurang produktif. Hal ini terjadi juga di Pulau Pramuka, bahwa pendidikan bagi perempuan nelayan masih kurang memadai, dimana sebagian besar perempuan nelayan hanya tamat Sekolah Dasar (SD) atau Sekolah Menengah Pertama (SMP). Keterbatasan mengakses dana pendidikandan sulitnya mendapat perijinan dari orang tua untuk melanjutkan sekolah karena dituntut membantu perekonomian keluarga.

\section{Pendekatan Empowerment (penguatan diri)}

Asumsi dasar dari pendekatan empowerent berkaitan dengan hubungan kekuasaan dan pembangunan. Pendekatan ini berusaha mengidentifikasi kekuasaan dalam rangka meningkatkan kemandirian dan kekuatan internal perempuan dengan cara memberikan kekuasaan kepada perempuan melalui pendistribusian kembali kekuasaan di dalam dan di antara masyarakat. Proses pemilihan Ketua RT di Pulau Pramuka Kepulauan Seribu yang lebih mempercayai 
perempuan sebagai pemimpin menunjukkan warganya menilai bahwa kepemimpinan perempuan di Pulau Pramuka lebih fokus dan terorganisir dibandingkan pemimpin laki-laki. Dalamhalkinerjadan pembukuan, hasil kerja perempuan lebih rapi dan memuaskan. Selain itu, Ketua RT berperan juga sebagai opinion leader ketika warga membutuhkan solusi atau sekedar berkonsultasi. Informasi kesehatan bagi masyarakat Pulau Pramuka disampaikan dan disosialisasikan setiap bulan, misalnya informasi penanggulangan dan pencegahan penyakit Demam Berdarah (DB), sosialisasi menu makanan sehat untuk anak-anak, sosialisasi cara mencuci tangan dengan benar agar bersih dari kuman, kegiatanPAPSMEAR untuk ibu rumah tangga, informasi mengenai BAHAYA NARKOBA untuk remaja, informasi kesehatan tentang $\mathrm{KB}$ Pria dan masih banyak program-program lainnya. Selain sosialisasi program kesehatan, Ketua RT juga memantau kasus pelecehan seksual dan KDRT yang belum pernah terjadi di Pulau Pramuka. Sosialisasi berupa pelatihan keterampilan untuk meningkatkan keahlian perempuan nelayan serta kegiatan kerohanian seperti pengajian secara rutin dilakukan di Pulau Pramuka.

\section{KESIMPULAN DAN SARAN}

\section{Kesimpulan}

Diskriminasi yang merujuk pada ketidakadilan pelayanan dan akses terhadap individu tertentu, dimana perempuan sering kali ditempatkan sebagai golongan nomor dua atau yang didiskriminasikan.Para perempuan mandiri yang mampu menopang keluarga dari sisi ekonomi sering kali tak terlihat (invisible) akibat persepsi perempuan hanya bisa berperan dalam ranah domestik. Padahal, sama saja dengan laki-laki, perempuan bisa berperan dalam ranah publik.

Komunikasi internal maupun eksternal menjadi hal yang sangat esensial untuk meminimalkan segala bentuk diskrimasi terhadap perempuan. Komunikasi internal dalam keluarga, khususnya dengan suami sebagai pemimpin rumah tangga merupakan poin penting, sehingga perempuan dapat lebih berekspresi dan tidak lagi masuk dalam golongan bisu atau dibisukan (muted group).

Persepsi masyarakat yang tinggal di Pulau Pramuka terhadap kepemimpinan perempuan sangat positif. Masyarakat sangat memahami bahwa tugas Ketua RT tidak hanya membutuhkan kekuatan fisik, tetapi membutuhkan kekuatan mental dan kemampuan menjalin kerjasama dengan berbagai pihak secara berkesinambungan,karena berdampak pada kinerja Pulau Pramuka yang menjadi salah satu tujuan wisata bahari di Kepulauan Seribu.

Diversifikasi profesi yang dilakukan perempuan nelayan di Pulau Pramuka dilakukan dengan penuh kesadaran demi mempertahankan hidup keluarga tetapi menimbulkan dampak beban ganda bagi perempuan. Selain itu, perempuan nelayan tidak hanya mampu melakukan pekerjaan domestik rumah tangga, tetapi juga mampu mengolah hasil laut dan menjualnya. Perempuan Nelayan juga sangat paham dan 'bersahabat' dengan iklim,walaupun tidak mempelajariya secara formal.

\section{Saran}

Kesetaraan gender pada kepemimpinan Ketua RT di Pulau Pramuka dapat dioptimalkan melalui pelatihan-pelatihan komunikasi persuasif bagi Ketua RT, sehingga memiliki skill dalam 
mengkomunikasikan

program-

programnya

\section{DAFTAR PUSTAKA}

Devito JA. 1997. Komunikasi Antarmanusia. Edisi ke 5. Jakarta : Professional Books.

Fargomeli F. 2014. Interaksi Kelompok Nelayan dalam Meningkatkan Taraf Hidup di Desa Tewil Kecamatan Sangaji Kabupaten Maba [ID]. Journal Acta Diurna Vol.3 No.3.

Griffin EM. 2000. A First Look at Communication Theory. New York [US]: McGraw-Hill Companies.

Imron. 2003.Pengembangan Ekonomi Nelayan dan Sistem Sosial Budaya. Jakarta : Gramedia.

Kramarae C. 1981. Women and Men Speaking, Frameworks for Analysis. Rowley [ID]: New Bury House Publishers

Krolokke C, Sorensen AS. 2006. Gender Communication Theories and Analyses: From Silence to Performance. California [US]: Sage Publications Inc.

Kusnadi. 2004.Mengatasi Kemiskinan Nelayan Jawa Timur :Pendekatan Terintegrasi.Yogyakarta [ID] : Pembaharuan.

Lippa, Richard A. 2005. Gender, Nature, and Nurture. New Jersey [US] : Lawrence Erlbaum Associates Inc. Masitho BD, Lestari P, Herna MS. 2013. Kehidupan Sosial Ekonomi
Perempuan dalam Masyarakat Nelayan di Desa Panjang Baru Kecamatan Pekalongan Utara.Jember [ID]. Jurnal Unnes Civic Educational Journal Vol 2(2).

Mosse JC. 1996. Gender dan Pembangunan. Yogyakarta [ID] : RIFKA ANNISA bekerjasama dengan Pustaka Pelajar.

Mosser CON. 1999. Gender Planning in the Third World : Meeting Practical and Strategic Gender Needs. World Development.

Narwoko JD. Suyanto B. 2004. Sosiologi : Teks Pengantar dan Terapan. Edisi keempat. Jakarta [ID] : Kencana Prenada Media Group.

Puspitawati H. 2009. Bahan Ajar Mata Kuliah Pengantar Ilmu Keluarga. Bogor[ID]. Fakultas Ekologi Manusia (FEMA) IPB.

Rakhmat J. 1998. Psikologi Komunikasi. Bandung [ID] : Rosdakarya.

Sastrawidjaya. 2002. Nelayan dan Kemiskinan.Jakarta [ID] : Pradnya Paramita.

Suryani T. 2008. Perilaku Konsumen Implikasi pada Strategi Pemasaran.Surabaya [ID] : Graha Ilmu.

Townsley. 1998.Analisis Pengentasan Kemiskinan Bagi Masyarakat Nelayandi Wilayah Kecamatan Paciran Kabupaten Lamongan.

Widodo. 2006.Marginalisasi dan Eksploitasi Perempuan Usaha Mikro di Pedesaan Jawa.Bandung [ID] : Yayasan Akatiga. 